Fetus

lecithin/sphingomyelin ratio lung lavage

lung surfactant phosphatidylcholine

respiratory distress syndrome

thyrotropin-releasing hormone

\title{
Thyrotropin-Releasing Hormone Increases the Amount of Surfactant in Lung Lavage from Fetal Rabbits
}

\author{
SEAMUS A. ROONEY, ${ }^{(38)}$ PAMELA A. MARINO, LAURICE I. GOBRAN, IAN GROSS, AND \\ JOSEPH B. WARSHAW \\ Department of Pediatrics, Division of Perinatal Medicine, Yale University School of Medicine, New Haven, \\ Connecticut, USA
}

\begin{abstract}
Summary
Administration of thyrotropin-releasing hormone (TRH) to pregnant rabbits at 25 and 26 days of gestation results in increased pulmonary surfactant production by the fetus at 27 days (full term is 31 days). There was $60 \%$ more total phospholipid and $150 \%$ more phosphatidylcholine (the major component of surfactant) in the lung lavage from the fetuses in the treated group than in that from the controls. Lung lavage from the fetuses in the treated litters contained $13.4 \pm 1.6 \mu \mathrm{g}$ of total phospholipid phosphorus $/ \mathrm{g}$ lung dry wt and $5.6 \pm 1.1 \mu \mathrm{g}$ of phosphatidylcholine phosphorus while that from the fetuses in the control litters contained only 8.2 $\pm 1.1 \mu \mathrm{g}$ and $2.2 \pm 0.4 \mu \mathrm{g}$, respectively. The phosphatidylcholine/ sphingomyelin ratio increased from 1.0 in the lavage from the controls to $\mathbf{2 . 2}$ in that from the treated group. These changes in lung lavage phospholipid content and composition are in the direction of increased lung maturation. TRH administration had no effect on the incorporation of choline into phosphatidylcholine in fetal lung slices. These data suggest that TRH stimulates surfactant release rather than synthesis.
\end{abstract}

\section{Speculation}

TRH has a physiologic role in fetal lung maturation and surfactant production. It may potentially be used in the prevention of the respiratory distress syndrome in humans.

Pulmonary surfactant, phospholipid-rich material which lines the alveoli and prevents atelectasis (12), is produced by the fetal lung towards the end of gestation (27). Insufficient surfactant at birth is believed to be the cause of the respiratory distress syndrome of the newborn (11). It has been reported that infants with the respiratory distress syndrome have lower levels of thyroxine and triidodthyronine than those who do not develop the disorder $(1,7,19)$. Direct administration of thyroxine to fetal rabbits has been reported to accelerate fetal lung maturation and surfactant production as determined by morphologic and surface-physical paramaters (28). It also increased the amount of phosphatidylcholine, the major surface-active component of surfactant $(12,27)$, in lung lavage (22).

Thyroid production of thyroxine and triiodothyronine is controlled by the pituitary hormone thyrotropin. Thyrotropin release, in turn, is controlled by the hypothalamic agent L-pyroglutamylL-histidyl-L-prolyl amide (TRH). Thyroxine, triiodothyronine, and thyrotropin do not cross the placenta to any appreciable extent, but TRH does (3). In this preliminary report, we show that administration of TRH to pregnant rabbits increases the amount of surfactant phospholipid in lung lavage from the fetuses.

\section{MATERIALS AND METHODS}

Pregnant rabbits (New Zealand White), whose breeding time was known to within $2 \mathrm{hr}$, were obtained commercially (30). TRH

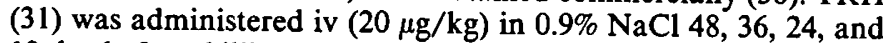
$12 \mathrm{hr}$ before killing at 26 or 27 days of gestation. 9-Fluoro$11 \beta, 17,21$-trihydroxy-16 $\beta$-methylpregna-1,4-diene-3,20-dione (betamethasone) in phosphate buffer (Celestone Soluspan) (32) was administered intramuscularly $(0.2 \mathrm{mg} / \mathrm{kg})$ to another group of rabbits 48 and $24 \mathrm{hr}$ before killing. Appropriate controls were similarly administered either iv $0.9 \% \mathrm{NaCl}$ or intramuscular (im) phosphate buffer.

The doe was anesthesized with sodium pentobarbital $(80 \mathrm{mg} /$ $\mathrm{kg}$ ) and the fetuses were delivered by cesarean section. The lungs were lavaged in situ with $0.9 \% \mathrm{NaCl}$ as described previously (23). Lipids were extracted from the lung lavage and residual lung tissue with chloroform and methanol and the phospholipids were fractionated into individual components by thin layer chromatography (23). Phospholipids were quantitated by phosphorus assay (8). The phospholipid content is expressed per gram of lung dry weight (obtained on lyophilization of the lavaged lung tissue).

The incorporation of choline into phosphatidylcholine in lung slices was measured by a modification of the procedure of Epstein and Farrell (10). Freshly-excised lung was chopped into slices 0.5 $\mathrm{mm}$ thick with a McIlwain tissue chopper (33). After a $10 \mathrm{~min}$ preincubation, the slices (2-6 mg of protein) were incubated with $1 \mu \mathrm{Ci}$ [methyl- ${ }^{14} \mathrm{C}$ ]choline (34) $(57 \mathrm{Ci} / \mathrm{mole})$ for $1 \mathrm{hr}(10)$. The reaction was stopped in ice-water and the slices were washed with ice-cold $0.9 \% \mathrm{NaCl}$. The tissue was homogenized and aliquots were removed for protein assay by the procedure of Lowry et al. (15) and lipid extraction by the procedure of Bligh and Dyer (4). After thin layer chromatography on Quantum LQD plates (35) in chloroform-methanol-7 $\mathrm{M} \mathrm{NH}_{4} \mathrm{OH}$ (60:35:5, by volume), the radioactivity content of the phosphaidylcholine band was determined in Liquifluor (34). Incorporation of choline into phosphatidylcholine was linear for at least $3 \mathrm{hr}$ under these conditions.

\section{RESULTS}

The effect of TRH administration to the doe on the phospholipid content and composition of lung lavage and lavaged lung tissue from the fetal rabbits is shown in Table 1 . There was $60 \%$ more total phospholipid and $150 \%$ more phosphatidylcholine in the lavage from the treated animals than in that from the controls. Phosphatidylcholine increased from $25 \%$ of the total in the controls to $37 \%$ in the TRH-treated animals while sphingomyelin decreased from $30 \%$ to $21 \%$. This resulted in a greater than 2 -fold increase in the phosphatidylcholine/sphingomyelin ratio. These changes, which were statistically significant, are in the direction of increased lung maturation (23) and are similar to those which we 
Table 1. Effect of TRH on fetal rabbit lung phospholipid content and composition ${ }^{1}$

\begin{tabular}{|c|c|c|c|c|}
\hline & Control & TRH treated & Treated/control & $P$ \\
\hline \multicolumn{5}{|l|}{ Lung lavage } \\
\hline \multicolumn{5}{|c|}{$\begin{array}{l}\text { Phospholipid content ( } \mu \mathrm{g} \text { phospholipid phosphorus/g lung dry wt) } \\
\text { Pung lave }\end{array}$} \\
\hline Total phospholipid & $8.2 \pm 1.1$ & $13.4 \pm 1.6$ & 1.6 & $<0.02$ \\
\hline Phosphatidylcholine & $2.2 \pm 0.4$ & $5.6 \pm 1.1$ & 2.5 & $<0.02$ \\
\hline \multicolumn{5}{|c|}{ Phospholipid composition (\% phospholipid phosphorus) } \\
\hline Phosphatidylcholine & $25.0 \pm 2.0$ & $36.8 \pm 3.9$ & 1.5 & $<0.025$ \\
\hline Phosphatidylethanolamine & $9.8 \pm 0.9$ & $7.0 \pm 0.9$ & 0.7 & $<0.05$ \\
\hline Sphingomyelin & $30.3 \pm 2.6$ & $21.1 \pm 2.0$ & 0.7 & $<0.01$ \\
\hline Phosphatidylinositol + phosphatidylserine & $12.4 \pm 1.1$ & $13.5 \pm 1.5$ & 1.1 & $\mathrm{NS}^{2}$ \\
\hline Lysophosphatidylcholine & $9.3 \pm 1.0$ & $9.3 \pm 1.6$ & 1.0 & $\mathrm{NS}^{2}$ \\
\hline Other acid phospholipids ${ }^{3}$ & $14.0 \pm 0.7$ & $11.5 \pm 1.2$ & 0.8 & $\mathbf{N S}^{2}$ \\
\hline Phosphatidylcholine/sphingomyelin ratio & $1.0 \pm 0.2$ & $2.2 \pm 0.4$ & 2.3 & $<0.05$ \\
\hline \multicolumn{5}{|l|}{ Lavaged lung tissue } \\
\hline \multicolumn{5}{|c|}{$\begin{array}{l}\text { Phospholipid content (mg phospholipid phosphorus/g lung dry wt) } \\
\text { Lavaged }\end{array}$} \\
\hline Total phospholipid & $3.5 \pm 0.3$ & $3.7 \pm 0.1$ & 1.1 & $\mathrm{NS}^{2}$ \\
\hline Phosphatidylcholine & $1.4 \pm 0.2$ & $1.3 \pm 0.2$ & 0.9 & $\mathbf{N S}^{2}$ \\
\hline
\end{tabular}

' The rabbits were killed at 27 days as described in Materials and Methods. Lavage and lavaged lung tissue from all fetuses in each litter were pooled for analysis. The data are the means ( \pm SE) from 13-15 TRH treated and 10-11 control litters. Statistical analysis was by $t$ test for independent variables.

${ }^{2}$ Not significant $(P>0.05)$.

${ }^{3}$ The other acidic phospholipids consisted of phosphatidylglycerol and lysobisphosphatidic acid with perhaps a trace of cardiolipin.

Table 2. Effect of maternal administration of TRH or betamethasone on the incorporation of choline into phosphatidylcholine in fetal rabbit lung slices ${ }^{1}$

\begin{tabular}{lccc}
\hline Treatment group & $\begin{array}{c}\text { Choline incorporation } \\
\text { (cpm/hr/mg of protein) }\end{array}$ & $\begin{array}{c}\text { Treated/ } \\
\text { control }\end{array}$ & $P$ \\
\hline Control & $2920 \pm 179(12)$ & & \\
TRH & $2875 \pm 135(5)$ & 1.0 & $\mathrm{NS}^{2}$ \\
Betamethasone & $5492 \pm 1013(4)$ & 1.9 & $<0.002$ \\
\hline
\end{tabular}

I TRH was administered iv twice a day and betamethasone im once a day at 24 and 25 days of gestation. The animals were sacrificed at 26 days as described in Materials and Methods. Because there was no difference between the two sets of controls, these data were combined. The data are the means ( \pm SE) from the number of litters indicated in parentheses. Statistical analysis was by $t$ test for independent variables.

${ }^{2}$ Not significant $(P>0.05)$.

have previously observed after direct administration of cortisol (20) and thyroxine (22) to fetal rabbits, as well as betamethasone to the doe (21), at the same stage of gestation.

TRH administration had no effect on the phospholipid content or composition of the lavaged lung tissue. This is similar to the effect of cortisol administration (20) and is not surprising because there is little developmental change in the total phospholipid or phosphatidylcholine contents of lavaged fetal rabbit lung (23). Because the phospholipids in lung lavage account for only $0.2-$ $0.3 \%$ of the total pulmonary phospholipids or phosphatidylcholine at 27 days of gestation (22), a change in lavage phospholipid content would not necessarily be reflected by a change in tissue content.

Corticosteroids are known to stimulate the synthesis of phosphatidylcholine in the fetal lung $(11,27)$. To determine whether TRH has a similar effect on synthesis, the effect of maternal TRH and betamethasone injection on the incorporation of choline into phosphatidylcholine in fetal lung slices were compared. In these experiments, the intracellular pool size of choline is unknown. Thus, factors which influence choline pool size might have an apparent effect on phosphatidylcholine synthesis. As shown in Table 2, while betamethasone stimulated the incorporation of choline into phosphatidylcholine by over $90 \%$, TRH had no effect. The effect of the hormones on choline incorporation into phosphatidylcholine was measured at 26 days of gestation, before the normal developmental surge in phosphatidylcholine synthesis (21). Previous experience with betamethasone indicates that the stimulatory effect of the steroid is not seen at $27-29$ days (21).
Similarly, TRH had no effect on the incorporation of choline into phosphatidylcholine in lung slices at 27 and 28 days of gestation after injection at 25-26 and 25-27 days, respectively.

At delivery, 30 of a total of 155 fetuses (19\%) in the TRHtreated group were dead. This compared with 10 of 341 (3\%) and 19 of $195(10 \%)$ in the control and betamethasone-treated groups, respectively. Administration of TRH had no effect on the weight of the live fetuses at delivery. At 27 days of gestation, 14 fetuses in two litters from control rabbits weighed $25.9 \pm 1.1 \mathrm{~g}(\mathrm{SE})$, while 17 fetuses in two litters from TRH-treated rabbits weighed 24.0 $\pm 1.2 \mathrm{~g}(P>0.3)$.

\section{DISCUSSION}

The data presented here suggest that TRH stimulates the release of surfactant into the alveoli. Unlike corticosteroids (11,27), however, it does not appear to stimulate the synthesis of the major component of surfactant, at least at the stage of development examined. The mechanism by which TRH stimulates surfactant release remains to be established. There are a number of possibilities. TRH crosses the placenta (3) and may stimulate production of fetal thyroid hormone. Thyroxine has previously been shown to increase the amount of surfactant in fetal rabbit lung lavage $(22,28)$ and has also been shown to stimulate the release of surfactant in the adult rat $(18,25)$.

The effect of TRH may also be mediated via prolactin. TRH is known to stimulate the release of prolactin by the anterior pituitary (26). Recently, Hamosh and Hamosh (13) reported that administration of prolactin to fetal rabbits resulted in a 2.6 -fold increase in the amount of total lung dipalmitoylglycerophosphocholine, the major surface-active species of pulmonary phosphatidylcholine $(11,12,27)$. This, however, has not been confirmed (P.L. Ballard, personal communication). The effect of prolactin administration on lung lavage phospholipids has not been examined (13).

There is also evidence that surfactant production may be under neurohumoral control $(2,5,6,9,14,16,17,29)$. In view of the increasing evidence that TRH serves as a neurotransmitter acting independently of the pituitary (24), a direct effect of TRH cannot be excluded.

We administered TRH to the doe twice daily for two days. We chose a dose of TRH $(20 \mu \mathrm{g} / \mathrm{kg})$ which was similar to the dose (a single injection of $10 \mu \mathrm{g} / \mathrm{kg}$ ) administered to pregnant rhesus monkeys by Azukizawa et al. (3). In that study, TRH administration resulted in elevated blood levels of thyrotropin, thyroxine, triiodothyronine, and prolactin in the fetus and had no apparent 
side effects (3). Further studies are needed to determine whether the observed effects of TRH on surfactant production might be achieved with a lower, possibly less harmful, dose.

Clinical attempts to prevent the respiratory distress syndrome in the newborn by the prenatal administration of corticosteroids to women in premature labor are currently underway. Although thyroxine stimulates surfactant production in animals $(18,22,25$, 28 ), it has not been used to prevent the respiratory distress syndrome because it does not cross the placenta. Thyroxine would have to be injected into the fetus or into the amniotic cavity to be effective. Because TRH crosses the placenta (3), it may be of value in the prevention of the respiratory distress syndrome in human infants, if its safety is established.

\section{REFERENCES AND NOTES}

1. Abbassi, V., Merchant, K., and Abramson, D.: Postnatal triiodothyronine concentrations in healthy preterm infants and in infants with respiratory distress syndrome. Pediatr. Res., 11: 802 (1977).

2. Avery, M. E.: Pharmacological approaches to the acceleration of fetal lung maturation. Brit. Med. Bull., 31: 13 (1975).

3. Azukizawa, M., Murata, Y., Ikenoue, T., Martin, C. B. Jr., and Hershman, J. M.: Effect of thyrotropin-releasing hormone on secretion of thyrotropin, prolactin, thyroxine, and triiodothyronine in pregnant and fetal rhesus monkeys. J. Clin. Endocrinol. Metab., 43: 1020 (1976).

4. Bligh, E. G., and Dyer, W. J.: A rapid method of total lipid extraction and purification. Can. J. Biochem. Physiol., 37: 911 (1959).

5. Corbet, A. J. S., Flax, P., and Rudolph, A. J.: Reduced surface tension in lungs of fetal rabbits injected with pilocarpine. J. Appl. Physiol., 41: 7 (1976).

6. Corbet, A. J. S., Flax, P., and Rudolph, A. J.: Role of autonomic nervous system controlling surface tension in fetal rabbit lungs. J. Appl. Physiol., 43: 1039 (1977).

7. Cuestas, R. A., Lindall, A., and Engel, R. R.: Low thyroid hormones and respiratory-distress syndrome of the newborn. Studies on cord blood. N. Engl. J. Med., 295: 297 (1976).

8. Dodge, J. T., and Phillips, G. B.: Composition of phospholipids and of phospholipid fatty acids and aldehydes in human red cells. J. Lipid Res., 8: 667 (1967).

9. Enhorning, G., Chamberlain, D., Contreras, C., Burgoyne, R., and Robertson, B.: Isoxsuprine-induced release of pulmonary surfactant in the rabbit fetus. Am. J. Obstet. Gynecol., 129: 197 (1977).

10. Epstein, M. F., and Farrell, P. M.: The choline incorporation pathway: primary mechanism for de novo lecithin synthesis in fetal primate lung. Pediatr. Res., 9: 658 (1975).

11. Farrell, P. M., and Avery, M. E.: Hyaline membrane disease. Am. Rev. Resp. Dis., 111: 657 (1975).

12. Goerke, J.: Lung surfactant. Biochim. Biophys. Acta, 344: 241 (1974).

13. Hamosh, M., and Hamosh, P.: The effect of prolactin on the lecithin content of fetal rabbit lung. J. Clin. Invest., 59: 1002 (1977)

14. Hayden, W., Olson, E. B., Jr., and Zachman, R. D.: Effect of maternal isoxsuprine on fetal rabbit lung biochemical maturation. Am. J. Obstet. Gynecol., 129: 691 (1977).

15. Lowry, O. H., Rosebrough, N. J., Farr, A. L., and Randall, R. J.: Protein measurement with the Folin phenol reagent. J. Biol. Chem., 193: 265 (1951).

16. Massaro, D.: In vivo protein secretion by lung. Evidence for active secretion and interspecies differences. J. Clin. Invest., 56: 263 (1975).

17. Oyarzun, M. J., and Clements J. A.: Ventilatory and cholinergic control of pulmonary surfactant in the rabbit. J. Appl. Physiol., 43: 39 (1977)

18. Redding, R. A., Douglas, W. H. J., and Stein, M.: Thyroid hormone influence upon lung surfactant metabolism. Science, 175: 994 (1972).

19. Redding, R. A., and Pereira, C.: Thyroid function in respiratory distress syndrome (RDS) of the newborn. Pediatrics, 54: 423 (1974).

20. Rooney, S. A., Gobran, L., Gross, I., Wai-Lee, T. S., Nardone, L. L., and Motoyama, E. K.: Studies on pulmonary surfactant. Effects of cortisol administration to fetal rabbits on lung phospholipid content, composition, and biosynthesis. Biochim. Biophys. Acta, 450: 121 (1976).

21. Rooney, S. A., and Gross, I.: Effect of maternal betamethasone administration on synthesis of phophatidylcholine (PC) in fetal rabbit lung slices at different gestational ages. Physiologist, 20: 80 (1977).

22. Rooney, S. A., and Motoyama, E. K.: Biochemical studies on normal and hormone-accelerated development of pulmonary surfactant. In: Pulmonary Macrophage and Epithelial Cells. 16th Annual Hanford Biology Symposium, Energy Research and Development Administration Conference 760927. p. 162 (National Technical Information Service, U. S. Department of Commerce, Springfield, VA, 1977).

23. Rooney, S. A., Wai-Lee, T. S., Gobran, L., and Motoyama, E. K.: Phospholipid content, composition and biosynthesis during fetal lung development in the rabbit. Biochim. Biophys. Acta, $431: 447$ (1976)

24. Smith, J. R., La Hann, T. R., Chesnut, R. M., Carino, M. A., and Horita, A. Thyrotropin-releasing hormone: stimulation of colonic activity following intracerebroventricular administration. Science, 196: 660 (1977).

25. Tsurutani, H., Redding, R., Arai, T., Overs, J., and Constantine, H.: Thyroid hormone effect upon ${ }^{14} \mathrm{C}$-palmitate uptake by surfactant. Fed Proc., 33: 345 (1974).

26. Tyson, J. E., and Friesen, H. G.: Factors influencing the secretion of human prolactin and growth hormone in menstrual and gestational women. Am. J. Obstet. Gynecol., 116: 377 (1973).

27. Van Golde, L. M. G.: Metabolism of phospholipids in the lung. Am. Rev. Resp. Dis., 114: 977 (1976).

28. Wu, B., Kikkawa, Y., Orzalesi, M. M., Motoyama, E. K., Kaibara, M., Zigas, C. J., and Cook, C. D.: The effect of thyroxine on the maturation of fetal rabbit lungs. Biol. Neonate, 22: 161 (1973).

29. Wyszogrodski, I., Taeusch, H. W., Jr., and Avery, M. E.: Isoxsuprine-induced alterations of pulmonary pressure-volume relationships in premature rabbits. Am. J. Obstet. Gynecol., 119: 1107 (1974).

30. Gloucester Rabbitry, Chepachet, R.I.

31. Sigma Chemical Co., St. Louis, MO.

32. Schering, Kenilworth, N.J.

33. Brinkman, Westbury, N.Y.

34. New England Nuclear, Boston, MA.

35. Quantum Industries, Fairfield, N.J.

36. The authors thank Christine M. Wilson for excellent technical assistance.

37. This research was supported by grants HD-10192 and HD-08293 from the National Institute of Child Health and Human Development.

38. Requests for reprints should be addressed to: Seamus A. Rooney, Ph.D., Department of Pediatrics, Yale University, School of Medicine, 333 Cedar St., New Haven, CT 06510, USA.

39. Received for publication March 20, 1978.

40. Accepted for publication June 1, 1979. 